\title{
AN EXAMPLE OF FIT-FOR PURPOSE USE OF MATERIALS IN ROMAN ARCHITECTURE: P TEMPLE, SIDE, ANTALYA/TURKEY
}

\author{
GAMZE KAYMAK HEINZ \\ Faculty of Engineering and Architecture, Department of Architecture \\ Beykent University \\ Hadımköyyolu, 08034 Ayazağa, Sarıer, Istanbul, Turkey \\ e-mail: gamzekaymak@beykent.edu.tr
}

Keywords: Side, Pamphylia, Temple P, Fit-for Purpose Use of Material, Historical Structure

Abstract. The high-podium Roman Period temple, with a semi-circular plan scheme, was discovered by Lanckoroński and his team in Side, Turkey and named after ' $P$ ' in 1890 [1]. The temple was unearthed by Mansel [2] and his team in 1947 through archaeological excavations. In 2013, further studies started on the temple. The aim of the still ongoing work is to seek answers to such issues that haven't been clarified yet, as the plan scheme, to whom it was dedicated, and the date of construction.

In this context, the construction structure of the Temple $P$ was investigated during the present study based on in-situ and precise documentation: At least five different types of stones were classified by purpose, including conglomerate, travertine, sandstone, marble and rubble stone mixed with mortar as infilling material. It was seen that fit-to purpose use of the material was considered more important than the ideal and repeated dimensions of the building blocks. Moreover, local material was used except for the outsourced marble.

In addition to the large-sized clamps and dowels in the load-bearing core blocks of the walls, the spaces between the coatings and the load-bearing core were filled with mortar. In this construction technique, opus revinctum and opus caementitium were used together. The partition walls separating the three rooms of the lower floor and the vault cover made with mortar and formwork system belong to the construction period of the temple. However, there are indications that the outer walls, about 2,5 $\mathrm{m}$ thick, originated from the foundations of a precursor structure. Four construction stages of the pillar profiles of the orthostat coating blocks of the podium, each having different lengths, can be traced from the upper surface workmanship, without scalping. The podium, which is approximately 2,30 cm high, is reached by one main and two side stairs. Numerous, high quality marble blocks in front of the cella on the podium indicate the presence of a monumental entrance structure made in opus revinctum technique. Unlike the profiled orthostat blocks of the podium, which were processed in situ after assembly, the cassette and cornice blocks of the entrance structure were produced 'on the ground' previously. The restitution of the marble cassette ceiling of the monumental entrance structure has been developed by combining the 1:10 scale precision surveys of the blocks via a computer aided method. The efforts for a modular planning and production are witnessed in the construction of cassette ceilings. 


\section{INTRODUCTION}

The temple $\mathrm{P}$, with high podium and a plan scheme of slightly larger than a semi-circle, is about $100 \mathrm{~m}$ away from the Athena and Apollo temples dedicated to the chief gods of the city in the Ancient city of Side in Pamphylia region. The $231 \mathrm{~cm}$ high podium forms the lower floor of the temple with its three vaulted rooms. The semi-round cella over the podium has a linear entrance façade of $16.80 \mathrm{~m}$ to the west and a depth of $11.15 \mathrm{~m}$ measured at right angles from the middle of the façade. In front of the cella there is a filled-in platform forming the lower structure of the monumental entrance structure, bounded by orthostat coatings on both sides. The arrangement of the orthostats suggests the presence of a wide main staircase leading up to the podium to the west and a secondary staircase each from the northern and southern sides.

The lower floor, which houses three spaces connected to each other by door openings, has an outer wall thickness of $2.50 \mathrm{~m}$, excluding the outer orthostat coatings. The bottom level of the lower floor is below the street level. Today it is accessed from the partly collapsed vault cover; there is no external access (Figure $\mathbb{1}$ ).
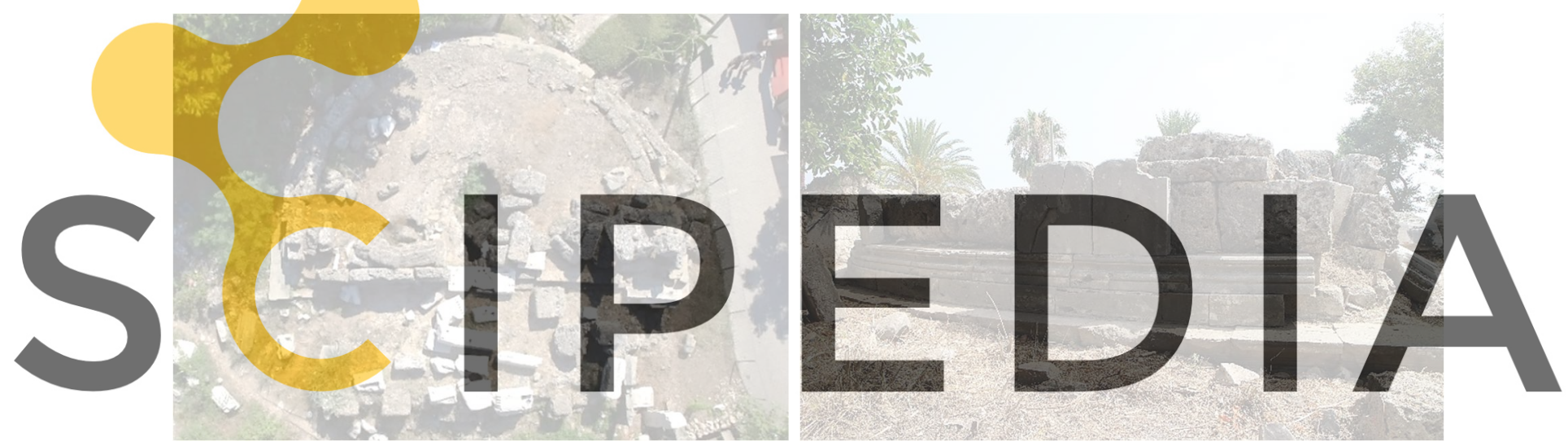

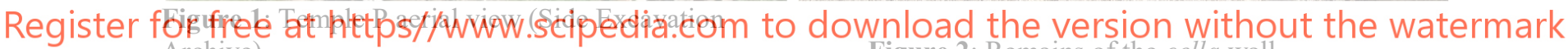
Archive)

Figure 2: Remains of the cella wall

\section{TYPE AND LOCATION OF MATERIALS USED AT TEMPLE}

In Roman architecture, adaptation to regional conditions was achieved by means of different construction techniques rather than by different building styles. Different construction techniques were developed as a result of the use of more economical and easily accessible local building materials [3].

Greek master builders meticulously paid attention to the harmony of stone joints in order to obtain repetitive measurements and maintained this rule for centuries. For the Roman building masters, the fit-for-purpose use of material was more important than the ideal and repetitive dimensions of the building blocks $[4,5]$.

Wright states that the precision of the Roman craftsmen in joining face stones lacked the ability to combine them with almost no joint spacings as in the Classical Greek workmanship. He argues that the Greeks used tools for 'forging' where Romans for 'cutting', and that the Romans preferred soft, less crystallized stones due to the difference in the methods of stonework [6]. The fact that Temple P, a Roman Temple, had six different types of stones in 
various sizes, distributed in accordance with the location and construction technique, confirms these claims:

Table 1: Types of stones used in Temple $P$

\begin{tabular}{l|l}
\hline Conglomerate & Foundations \\
\hline Travertine & In the carrier core of the cella wall \\
\hline Sandstone & Orthostat coatings \\
\hline Marble & $\begin{array}{l}\text { At two-storey monumental entrance structure and cella gate, } \\
\text { at the inner coating of cella in thin plates }\end{array}$ \\
\hline Face stone & On the vault cover of the lower floor \\
\hline Rubble & In the filling of the lower structure of the monumental entrance structure \\
\hline
\end{tabular}

There is a distinctive hierarchical structure among the building materials used in the temple, according to their functioning as bearing unit or surface layer. Also, different applications regarding the mortar use are seen, depending on the location, such as whether there is a mixture of bricks (rough and fine construction works) or not.

\subsection{Conglomerate}

Conglomerate (conglomerāre, Lat. = gathered into a ball or rounded mass), local "natural concrete' or so-called ' occurs spontaneously in the remains of sea creature pebbles in the conglomerate are not rounded but angular, they varies according to the color distribution of pebles [7,8].

Lamprecht suggests it can be asserted that the master builders were inspired by the

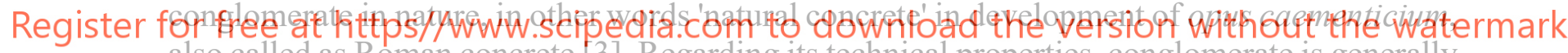
also called as Roman concrete [3]. Regarding its technical properties, conglomerate is generally a difficult-to-cut building material; it is difficult to obtain smooth-edged blocks because the hard gravels within it are broken in heaps during the production and processing of the blocks. Therefore, the location of their use is generally determined by the size of the gravel grains. The smaller the grain size, the better it is suitable for fine profiling. In Side, fine-grained conglomerate blocks as used in the jambs and lintels of some gates on the walls were profiled with fascia. The conglomerate used in Temple P has a coarse-grained structure (Figure 3-4).

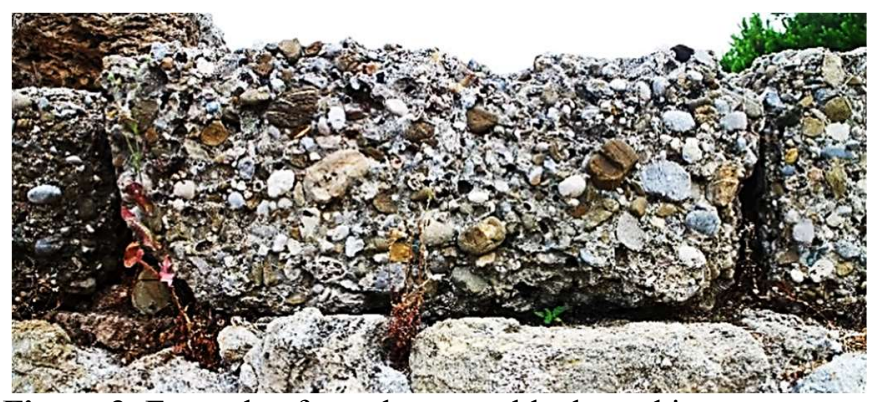

Figure 3: Example of conglomerate block used in foundations

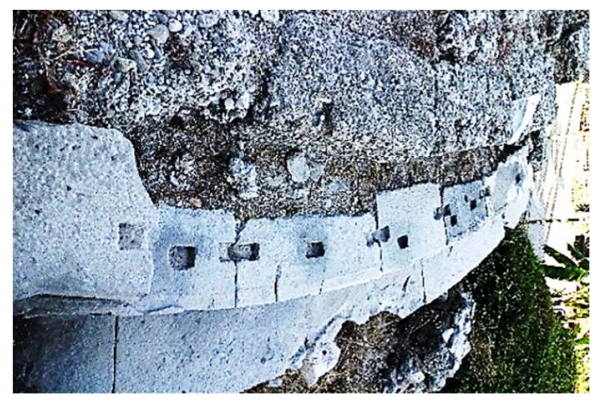

Figure 4: Cella wall foundation 


\subsubsection{Use of conglomerate in the structure: foundations}

It can be observed that the master builders had more confidence in conglomerates, which was frequently used in the antique buildings of Side, compared to the travertine in static terms. They preferred conglomerate for the point foundations set for the frontal columns of the monumental entrance structure, the continuous, uninterrupted foundation of the second row of columns, and in the lowest sequence of the cella wall, i.e. where the structure should be 'stronger' in static terms (Figure 4).

The conglomerate blocks, which form the lower row of the travertine bearing core of the cella wall, were aligned side by side on the massive wall of the lower floor. They contained clamp slots indicating that they were connected to the sandstone blocks at the same level and in front of them. However, they do not have a clamp connection between each other or dowel slots for fixing the next row of stones onto them. This indicates the fact that the master builders were more concerned with the pull and push force than the compressive force. There are no dowel holes on the upper surfaces of the conglomerate blocks forming the basis of the columns. The singular column foundations or 'continuous conglomerate blocks' of the monumental entrance structure also function as a binder and reinforcer in static terms, preventing the sliding of small sized rubble and fill material forming the substructure.

\subsection{Travertine}

Travertine is a type of large perforated limestone formed by continuous addition of lime to the fossilized residues of seashells. The formation of these stones can be clearly understogd
from the fossilized residues of living beings ar the traces they left on the stone. Travertines.
which are available in quite different qualities, are generally very robust and weather resistant.
It takes a long time for travertinef to reach ideal properties such as having different color layers
used by sculptors, being able to be polished well and weather resistant [7].

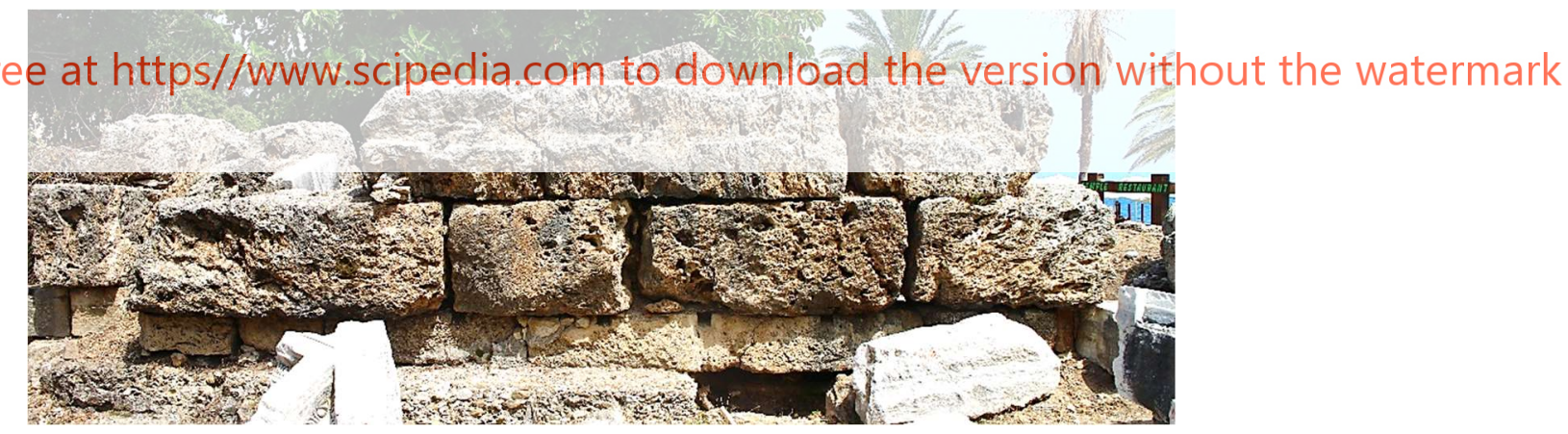

Figure 5: Travertine blocks used in the bearing core of cella

\subsubsection{Use of travertine in the structure: the inner core of the cella wall}

The travertine used in Temple $\mathrm{P}$ is of lime tuff, which had not yet completed its crystallization process. These hard-to-break, porous (thanks to the traces of the fossils), and hard travertines with fossil traces are not suitable to be used as surface layers because of several pores and are not suitable for producing blocks of standard dimensions. The cella wall of the temple was built by a three-walled construction technique. Here, the carrier core is formed by travertine blocks behind the façade coverings and on invisible surfaces (Figure 5). Sandstone 
was used as a coating material on the outside of travertine. A $2,2 \mathrm{~cm}$ thick marble cladding material was used inside the wall, facing the cella space.

On the upper floor, travertine blocks were brought together side by side in longer format in the in-situ wall part of the linear western facade of the cella and in shorter format in the rounding part of the cella wall (Figure 2-3). This wall technique, where the 6-8 cm gap left between the inner and outer claddings is filled with mortar, did not require that the travertine blocks were very precise in size or the blocks were cut circularly. Long clamps up to $30 \mathrm{~cm}$ were used to cover the mortar-filled distance between travertine blocks and cladding blocks. In the northern corner of the cella, there is an in situ $96 \mathrm{~cm}$ high and $20 \mathrm{~cm}$ thick orthostat-style sandstone outer crust and $55 \mathrm{~cm}$ thick travertine array (Fig. 2). The dowel slots on the inward side of the travertine blocks and the remains of 2,2 cm thick marble slabs over the surface levelled by 5-6 $\mathrm{cm}$ mortar indicate that the cella was covered with marble.

\subsection{Sandstone}

As mentioned, the conglomerate and travertine blocks were used only in foundations and in the bearing core, on the grounds that they failed to meet the expectations as surface layer. Homogeneous, smoothly cut and processed gray, local sandstones with fine pores were used on the sides of the temple that were visible from outside. Static integrity was achieved with dowels and clamps, where sandstone met conglomerate and travertine. Mortar was used as additional support.
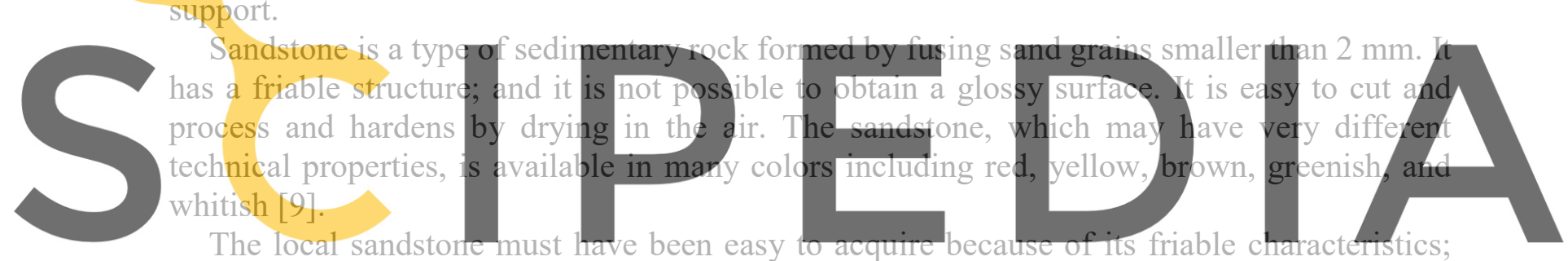

The local sandstone must have been easy to aecuire because of its friable chatacteristics;

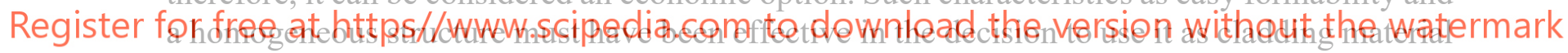

at the podium and Temple P, with a circular-formed cella. Surface damages on this type of stone occur in the form of crumbling, wearing, and scouring. Due to the bedding property fractures generally occur in thin layers. Due to this feature, the top and bottom profiles of orthostats, the block of the cella wall after the base, and the round architrave-frieze block of cella were not embellished.

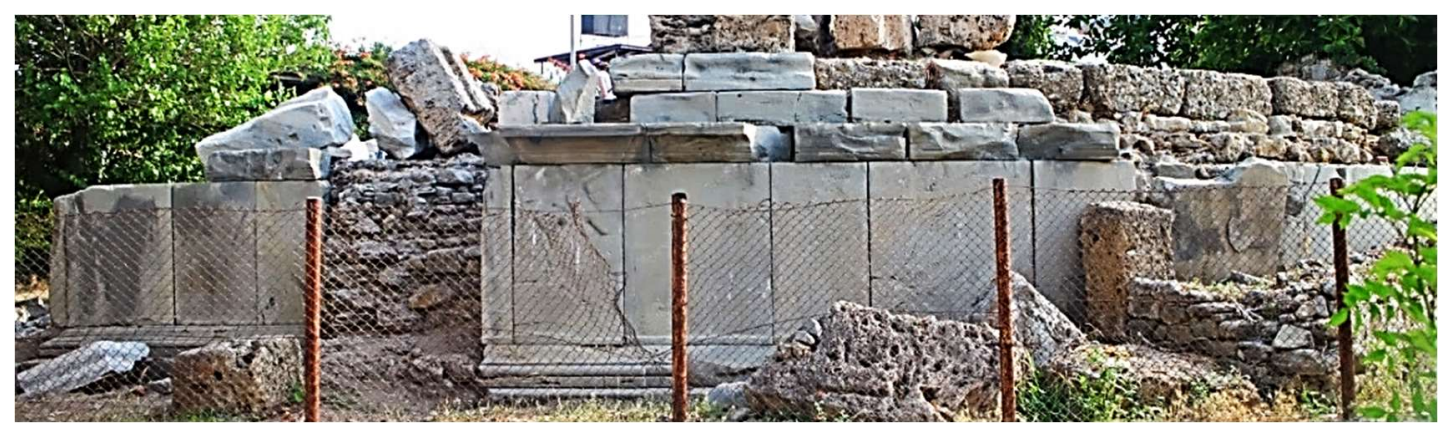

Figure 6: Sandstone orthostat blocks used for podium coating 


\subsubsection{Use of sandstone in the structure: orthostat coatings}

The 2,50 m thick outer wall of the lower floor of the temple was cladded with orthostat blocks of various lengths made of approximately $20-30 \mathrm{~cm}$ thick sandstone (Figure 6).

Aschenheim suggests that the vertical stones (orthostats) placed in front of the masonry made of rubble stones were taken from Greek Architecture of the Archaic Period and that the 'tripartite base' was introduced by incorporating the foot and 'head' profiles [10]. Hueber asserts that the first use of orthostats was based on building physics, and that moisture, as drawn from the soil with homogeneous and upright blocks, was prevented from damaging the building. Furthermore, this principle of construction was transformed into a design and style tool over time [11].

The first connection between the $146 \mathrm{~cm}$ high orthostats of the podium and the massive circular wall was made by placing the profile blocks, which were deeper than the orthostats on top, onto this thick wall. After the orthostat was placed in its location, the 5-6 cm gap with the wall was filled in with mortar and clamped to the rearward block. Thus, in terms of structural physics, any moisture that might have occurred would be directed upwards through the filling mortar between the orthostat and the massive wall. This would possibly prevent the mortar from disintegration by drying out, before trying to drain out of the dense stone texture of the vertical blocks.

Orthostat blocks of various lengths and thicknesses indicate that the stones were not ordered in standard sizes but delivered in such sizes that satisfied the 'preliminary data', perhaps in the

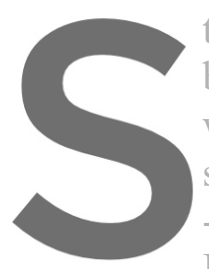
terms of lower and upp brought to the construc within easy reach. While this is surfaces of the blocks wo -perhaps left as they can It's even advantageous if the
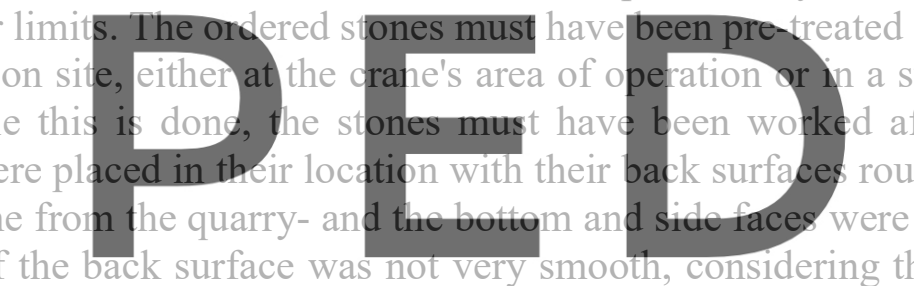

with the existing wall would be filled in with mortar. This is because five stages can be

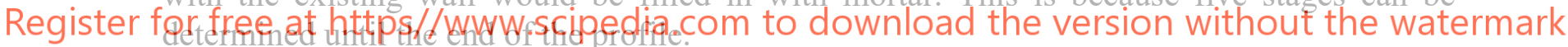

The upper surface workmanship of the foot profiles, which are $14-15 \mathrm{~cm}$ deep, approximately $31 \mathrm{~cm}$ high and of different lengths, such as the orthostat biocks of the podium, indicate that these blocks were roughly machined with stonemason's chisel and placed as cut at a certain angle in the direction of the profile. This type of assembly, which can only be done from the front, requires a clearance on the rear surfaces to ensure precise placement of the blocks. In a section showing the untreated stage of the profile, it is found that three dovetailshaped 'docking slots' were drilled into the upper surface of the stone in order the orthostat block above could be aligned and pushed towards the neighboring stone or backwards. Thus, the orthostat block was placed in its position as much as it was possible, it must have been pushed to its the ideal position with the help of a lever. This lever detail in the foot profile must have been made after the orthostat block array was placed. From the differences in surface workmanship of the foot profile array of orthostats, it can be observed that the profile was brought to the desired final state in five stages. As for the section, the profile was not yet processed, the workmanship was completed, and that there were irregularities in the workmanship that continued beyond the joints: This proves that the surface layer was treated after assembly. On the front side, the marks of the stonemason's chisel are visible under the 
marks left by the stonemason's dredge. This detail shows that the final process was delayed after the completion of the construction.

\subsection{Marble}

All material used in the construction of Temple $\mathrm{P}$ is the local material, except for the marble preferred in the monumental entrance structure in front of the cella. Ward-Perkins states that only the 'marble style' was preferred in the monumental buildings of the Roman Empire in Pamphylia in the middle of the 2nd Century [12].

Inan suggests that the absence of a marble quarry near Side shows that the marble requirement for sculpture was met from outside [13]. However, the remains of many buildings in the city, and many of the statues and sculpture fragments that have been recovered show that marble was used in abundance. It also indicates that the overseas ordering and delivery of the material was successfully implemented. The marble brought from outside must have been processed in the city workshops.

Nolle acknowledges that the people of Side have rich donors from the wealthy strata, who were willing to pay the high price of overseas transport in order to give their cities a marble appearance by covering the local building materials with marble. He considered the same as a sign that it was very popular as a way to make oneself immortal by being memorialized on the buildings. As a matter of fact, the marble used in the monumental entrance structure in temple $\mathrm{P}$ in front of the cella and oriented towards the square must have been be acquired from

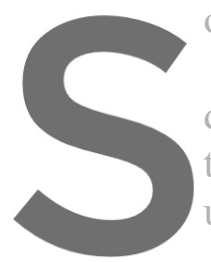

overseas.
Scientifically, marble is a discerned by naked eye

they are statically resist

used in Temple P; the fr

An important difference of marble compar
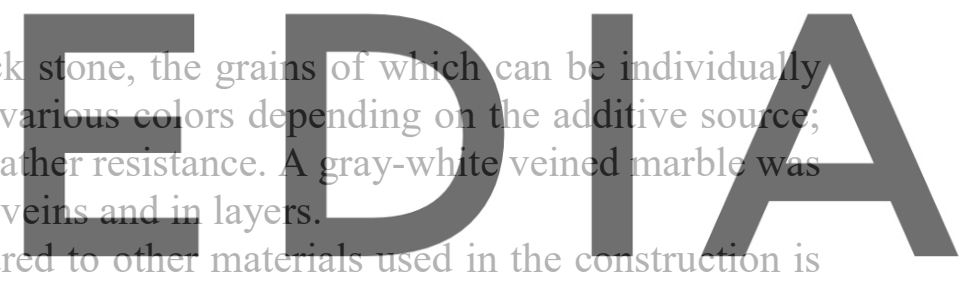

the construction technique. The richly decorated marble blocks of the monumental entrance

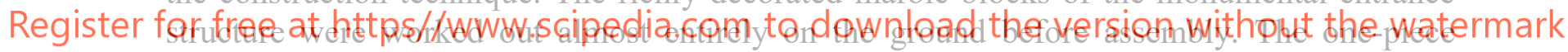

cassette and cornice blocks suggest that they might have been produced at accurate and precise sizes by taking measurements in place after the assembly of the columns and architraves. Like the ceiling cassettes of the stage building of Side ancient theater and the cassettes surrounding the cella of Tyche Temple, the cassettes of the entrance structure of Temple P were carved from a single block with all its profiles and frames.

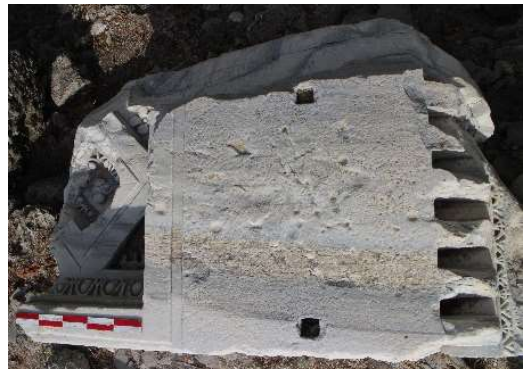

Figure 7: Cassette-Cornish block

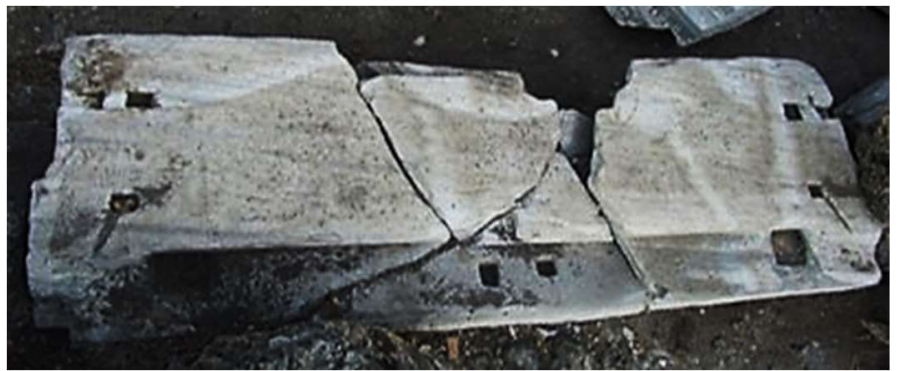

Figure 8: Marble threshold block of cella door 


\subsubsection{Use of marble in the structure: Monumental entrance structure (revinctum construction technique)}

There are many architectural blocks made of gray-white veined marble such as column body fragments, column bases, column caps, elaborately worked richly decorated cassette-cornices (Figure 7), architrave-frieze blocks with double-sided appearance, and tympanons on the platform in front of the cella. It is also understood from the in-situ threshold block (Figure 8) and the gate lintel that fell just in front of it that the door on the western wall of the cella was made of marble.

The technical connections between the blocks are limited to dowels; clamps were not considered necessary in the construction of the ceiling. There are remains proving that a lead channel was used in addition to iron dowels for the installation of columns and bases. Anathyrosis was not applied to the seating surfaces of cassette and toothed cornice blocks and the whole surface was smoothed to distribute the load over a larger area. It is seen in the single column cap available that the surface on which the architrave will sit was made higher by pulling back from the profiles. This, therefore, secured the profiles against compressive strength and fractures.

There are slots for two small lower dowels each on the two lower ends of the cassettes, where the clamps are not used and the frieze seats. With smooth machining of the side faces, the blocks were able to approach each other with zero clearance. Very few blocks have lifting holes. Use of deeper reliefs on visible surfaces and less deep reliefs on less visible surfaces in

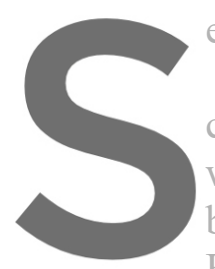
embellishments should to

Hoepfner suggests tha ceilings is Hieron in were brought togethe be as uniform as possib
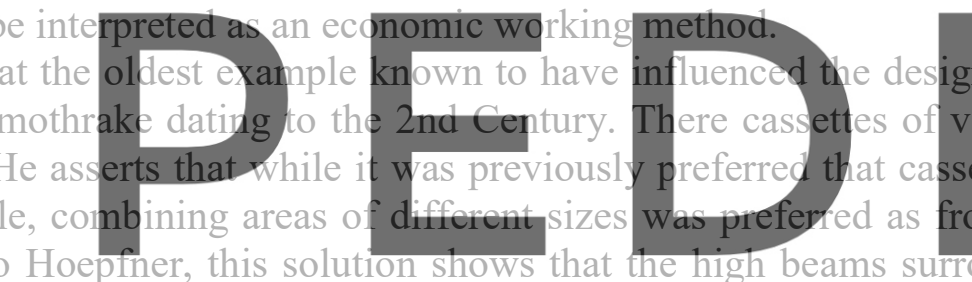

Hellenism. According to Hoepfner, this solution shows that the high beams surrounding the cassettes were considered disturbing, because they covered the painted or relief-decorated main Register for frees at thetpstbwWw scipedia.com to download the version without the watermark

The large cassette type at both ends of Temple P occupies a large area. In the parts close to the cella, many smaller cassettes were brought together, extending the cassette area, and therefore the field of view, to prevent the likelihood of a beam hindering the appearance.

\subsection{Face stone}

Opus caementicium technique was used in the vaulting of the rooms on the lower floor of Temple P. Gruben states that the vault construction, the most important invention of the Roman Period, was not prominent in the temple buildings, because it was preferred to adhere to the Classical Greek temple construction as proposed by Vitruvius [16]. This technique, which did not require a great deal of manual dexterity, could have been done by local builders well as by unskilled workers. To that end, use of rubble stone, mortar, and mold night have been enough. In Temple P, the vault cover was used only on the ceiling of the lower floor. The fact that not only rubble stones but also stones with smoothly cut side and bottom surfaces were used indicates that the stonemasons worked in the construction of the vault. 


\subsubsection{Use of face stone in the structure: vault cover of the lower floor (mortar and formwork system)}

The cradle vault cover in the middle of the lower floor starts at the same height on the two side walls and transfers the static load to those walls equally. On the underside of the barrel vault, from the semi-round shaped print marks left by the molds to the mortar, approx. It is still clear that logs with a diameter of $16 \mathrm{~cm}$ (round trunk of cut trees) have been used.

The apex of the half vaults in the triangular planned side rooms are positioned approximately $50 \mathrm{~cm}$ away from the wall separating the middle space in the southern room and approximately $70 \mathrm{~cm}$ in the northern room. They sit on this wall by reducing the height of the vault by only 6$7 \mathrm{~cm}$. They sit on the thick outer wall with a fairly steep incline in the other direction. Thus, the loads of the vaults of the side rooms were transferred to the $2.50 \mathrm{~m}$ thick outer wall. The vaulted cover of the triangular planned side rooms was mounted on a circular thick wall at an increasing height and irregular geometry towards the top of the triangle in the plan.

The fact that the vault was placed on the thick wall in such an irregular geometry suggests a repair that was conducted subsequently on the wall rather than a designed construction. During the Roman period, if the area, where a building was located, was to be reused, the building was not demolished and destroyed. Alternatively, the old building was covered with filling and incorporated into the foundations of the new construction. In Rome, for example, some of the walls of Nero's Golden House, built in 64-68 AD, were used as the basis for the Trajan Baths built in 109 AD [17].

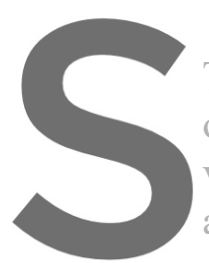

The wood formwoik The round form of wood th over the vault left by th visibility of the mold marks also suggests that the after the mold was removed. The front of the closed cave when they were buint, must have been which also forms the boundary of the platform in front of the podium to the temple, was closed

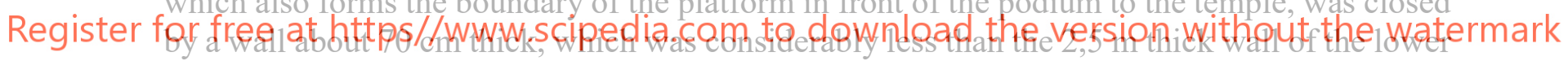
floor after dismantling and removing the mold used to build the vaults.

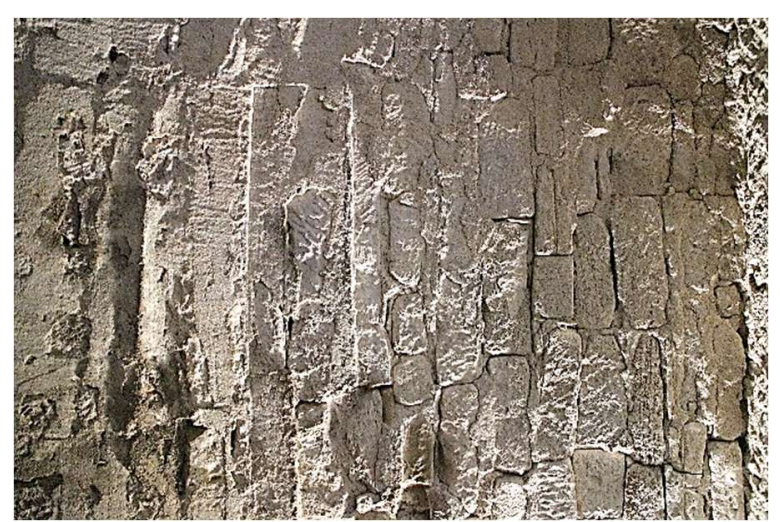

Figure 9: Vault cover of the lower floor

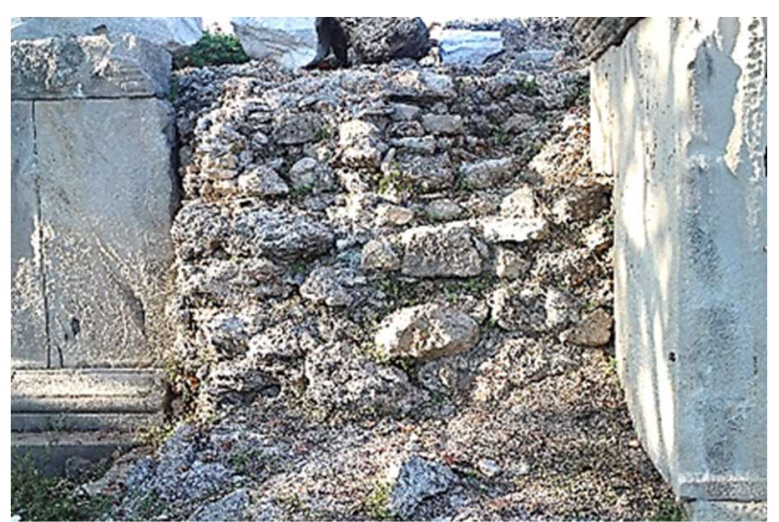

Figure 10: Infrastructure of one of the side stairs 


\subsection{Rubble (untreated) stone and its place of use: Infrastructure of the monumental entrance and stairs}

In addition to the conglomerate foundations, a mortar mixture without rubble stone and bats were used as the filling material for raising the infrastructure of the platform in front of the cella up to the podium level and for the infrastructure of the stairs. It is known that mortar was especially important for the Roman construction technique [18]. In Temple P, rubble stone, bats, and a mortar mixture without bats were used for the bases of the vault covers of the lower floor that were placed on the thick outer wall. They were also used for the filling of the platform, where the monumental entrance structure was located, in front of the cella (Figure 10). In general, two types of mortars were used: one without bat addition as seen in the masonry and fillings, and another one with bat addition, where there was contact with marble. As in today's buildings, rough and fine work was differentiated in construction.

\section{CONSTRUCTION TECHNIQUE AND STONEWORK}

In ancient times, while architectural ideas and aesthetic creativity were tested by means of application, special requests encouraged the development of the technique and generation of new building ideas.

Opus caementicium, one of the most important "inventions" in architectural history, which Ward-Perkins described as "a turning point in the history of architecture" [19] and Deichmann as "revolution of building technique" [20] had long been known when P Temple was built.

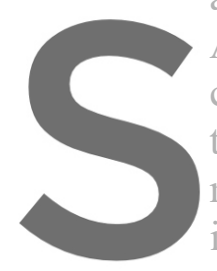
Although the foundations of the podium of
considered the oldest surviving example th
technique, where the gaps between the bedro
mortar was found at Belevi Mausoleum, a Hel
in Anatolia [22]. Thanks to "opus caementi
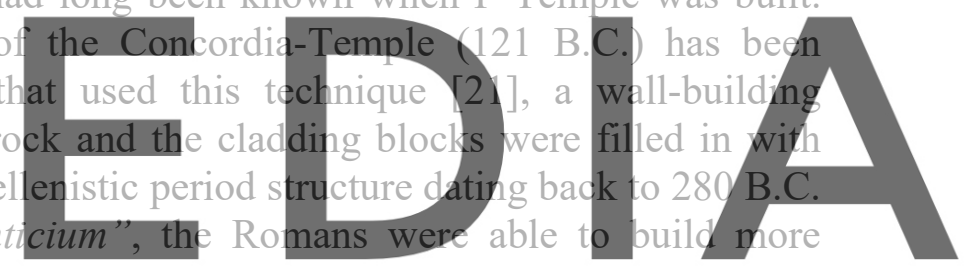

ambitious, more durable monuments with increasingly larger domes and vaults along with

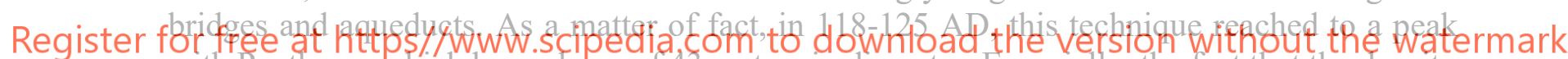
with Pantheon, which has a dome of 43 meters in diameter. Especially, the fact that the density

of the components of the mortar used in the Pantheon gradually decreases from the bottom to the top [23], suggests that they were very competent about statics and the said construction technique.

In his second book on building materials and construction techniques, Vitruvius compared the wall technique of the Roman and Greek structures: He criticized the way Romans used vertically positioned stones and filled in the gap with a mixture of mortar and broken stones with an aim to form the outer shell and the three-layered method with two outer shells and the filling wall between them. He stated that the Greeks made the whole wall massive, which consisted of an inner and outer shell made of carefully engineered stone blocks without using mortar and the core between them again made of smoothed stone blocks. He praised the Greek method of emplecton stating that the outer and inner shells were held together by clamping, stone blocks, or metals covering the entire width [24]. With its wall technique, Temple P is different from the two definitions by Vitruvius', and even that it is a combination of the two. The opella revinctum was used along with mortar in the construction technique of the cella wall of Temple P. Despite its coarse texture, the inner travertine block was prepared by cutting all the surfaces to have it function as filling in the wall. The mortar used in the space between the 
bearing core and the coatings does not have a bearing function. The load bearing function is predominantly assumed by the travertine core in this wall technique. Although Lamprecht asserts that generally the core wall was responsible for load bearing in concrete structures of the Roman period, he meant the core made by opus caementicium [3]. In Temple P, the travertine core layer assumes that function.

\section{CONCLUSIONS}

- $\quad$ The selection and distribution of materials suitable for the purpose of Temple P is only possible with great building experience and material knowledge. Because it requires an insight into not only the bearing capacity of the material, but also the likely movement and pressure forces that may occur in the structure.

- Master builders preferred to use as little material as possible in each period. This approach had a positive effect as a working method on the acceleration of the construction process and the construction economy. We can define this as rationalization: Nowadays, the concept of rationalization means the use of modern production methods, in which better results can be achieved with the same effort or the same results with less effort. It can be said that this approach also applies to Side building masters from during Antiquity. Use of opus caementicium and opus revinctum, where it's deemed necessary, is an example of the foregoing. It must have provided a rapid construction process beyond being an economic option.

- $\quad$ Nowadays, while there are standardized ready-made ceiling elements produced in high numbers taking into consideration a certain tolerance in dimension, a 'same style' production mode was preferred in 'Temple P', which allowed conducting adaptation processes during assembly. As it is today, the construction elements were pre-finished elsewhere as much as possible, in order to ensure easy and quick production during construction. However, no cassette element at Temple $\mathrm{P}$ is exactly the same as another but used as mirrored due to symmetry at most. Nevertheless, even in this state, it is a candidate of being a pioneer of prefabricated production.

Acknowledgements. The activities at Temple P are carried out under Side Excavations. Geodetic measurements; conducted in 2015 thanks to the financial support of Suna-İnan Kıraç AKMED Research Institute. The studies were supported by TUBITAK at Beykent University within the scope of 2232 BIDEB scholarship program between 2016-2018.

\section{REFERENCES}

[1] K. G. Lanckoroński, Städte Pamphyliens und Pisidiens I (1890)

[2] A. M. Mansel, E. Bosch ve J. İnan, 1947 Senesi Side Kazılarına Dair Önrapor - Vorläufiger Bericht über die Ausgrabungen in Side im Jahre 1947, TTK (1951).

[3] H.-O. Lamprecht, Opus Caementitium. Bautechnik der Römer (1996). RömischGermanisches Museum Köln, Beton-Verlag.

[4] E. R. Fiechter, Der Ionischer Tempel am Ponte Rotto in Rom. S. Maria Egiziaca. 
Mitteilungen des kaiserlich deutschen archäologischen Instituts. Band 21. 1906, 220-279. [5] H. von Hesberg, Römische Baukunst (2005).

[6] G.R.H. Wright, Ancient Building Technology, Vol.1, Historical Background, (2000). Leiden-Boston-Köln: Brill.

[7] A. Kieslinger, Gesteinskunde für Hochbau und Plastik. Fachkunde, für Steinmetz, Bildhauer, Architekten und Baumeister (1951). Wien: österreichischer Gewerbeverlag.

[8] E. M. Winkler, Stone in Architecture. Properties, Durability ${ }^{3}$ (1994). Berlin Heidelberg: Springer-Verlag.

[9] M.-H. Wanetschek, Naturstein und Architektur. Materialkunde und Anwendung Steintechnik (1992). München: Callwey: 16.

[10] C. Aschenheim, Der Sockel: seine Form und Entwicklung in der griechischen und hellenistisch-römischen Architektur und Dekoration von den ältesten Zeiten bis zur Verschüttung Pompejis. von M. Vetter (1910). VIII B1. (Zur Kunstgeschichte des Auslandes; 75), Straßburg: Heitz

[11] F. Hueber, Ephesos gebaute Geschichte. Sonderheft AW (1997)

[12] J. B. Ward-Perkins, Roman Imperial Architecture ${ }^{7}$ (1990). London: Penguin.

[13] J. İnan, Roman Sculpture in Side, TTK 5, 30a, Antalya bölgesinde araştırmalar 8. Researches in the Region of Antalya 8 (1975).

[14] J. Nollé, Side im Altertum. Geschichte und Zeugnisse I, Inschriften griechischer Städte aus Kleinasien 43 (Bonn 1993).

[15] W. Hoepfner, Zum Problem griechischer Holz- und Kassettendecken, in: Bautechnik der Antike, internationale Kolloquium in Berlin vom 15.-17. Februar 1990 veranstaltet vom Architekturreferat der DAI in Zusammenarbeit mit dem Seminar für klassische Archäologie der Freien Universität Berlin. Herausgegeben von Adolf Hoffmann, ErnstLudwig Shwandner, Wolfram Hoepfner und Grunnar Brands, Verlag Philipp von Zabern, Mainz am Rhein, (1991), 90-98.

[16] G. Gruben, Die Rolle der Architekten in der Geschichte, (50-58) in: Aus der Geschichte der Bautechnik, Fritz Scheidegger (ed.), Band 1: Grundlagen, (1990). Basel, Boston, Berlin: Birkhäuser Verlag.

[17] R. Mark (ed.), Vom Fundament zum Deckengewölbe: Großbauten und ihre Konstruktion von der Antike bis zur Renaissance, Basel [u.a.]: Birkhäuser 1995

[18] B. Cech, Technik in der Antike ${ }^{2}$ (2011), Darmstadt: Theiss Verlag.

[19] J. B. Ward-Perkins, Architektur der Römer (1975). Stuttgart: Belser

[20] F. W. Deichmann, Westliche Bautechnik im römischen und rhomäischen Osten, Mitteilungen des Deutschen Archäologischen Instituts, Römische Abteilung, Bd. 86, 1979, S. 473 f. Mainz.

[21] G. Haegermann, Vom Caementum zum Zement, in: Vom Caementum zum Spannbeton, Bd. 1, (1964). Wiesbaden: Bauverlag. 3-72

[22] G. Kaymak, Kültürel mirasın yapı malzemeleri tarihine katkı boyutu: Belevi Mausoleumu Örneği, in: TMMOB yayınları, 5. Ulusal Yapı Malzemeleri ve Sergisi Kongresi, Istanbul, 03-05 Kasim 2010, 205-218.

[23] H.-O. Lamprecht, Verwendung von Beton bei Wasserbauten in der Antike, Mitt.bl. BAW Nr. 65, Bundesverband der deutschen Zementindustrie, Köln 1989

[24] P. M. Vitruvius, Mimarlık Üzerine On Kitap (çev. S. Güven), İstanbul, 1990. 